\title{
Evaluation of the ecological state of the major streams located in Doon valley using diatoms as indicators
}

\author{
Rajbeer Singh $^{1^{*}}$, Prakash Nautiyal ${ }^{1}$ and RachanaNautiyal ${ }^{2}$ \\ ${ }^{1}$ Department of Zoology and Biotechnology H N B Garhwal University, Srinagar-Garhwal- 246174 (Uttarakhand), \\ INDIA \\ ${ }^{2}$ Nodal officer EDUSAT, Higher Education, Govt. of Uttarakhand, Dehradun (Uttarakhand), INDIA \\ *Correspondence author. E-mail: rajbeersinghkabsuri@gemail.com
}

Received: November 27, 2017; Revised received: January 13, 2018; Accepted: February 25, 2018

\begin{abstract}
Biological communities reflect overall ecological integrity (i.e. chemical, physical and biological integrity). Since the diatom species exhibit variation in tolerances to physical and chemical change in water, they are excellent indicators changes in their environment. Based on the dominant categories for each characteristic, the ecological state of the stream can be determined. This study evaluates the ecological state of the streams in Doon Valley. The diatom samples collected at regular monthly intervals from the twelve streams located in the eastern and western Doon were treated with acid-peroxide and mounted in Naphrax for species count at x1500. About 250-300 valves of diatom species were counted and Van Dam ecologic values were computed by OMNIDIA ver. 5.3. pH was alkaliphilous (4), salinity - fresh brackish (2) and oxygenation - continuously high (1) for most of the streams. Saprobity and trophic status was largely $\beta$-mesosaprobous (2) and eutraphentic (5), respectively. The Leclercq index also shows non-existent $(<10 \%)$ to low $(10-20 \%)$ organic pollution, degradation (IDSE=3.5-3.0) and moderate anthropogenic eutrophication (20.1-45\%) in most of the streams attributed to urbanization stress (62 MLD sewage). The water quality based on indices; IBD (Indice biologique diatomèes), IPS (Indice de polluo-sensibilite) and TDI (Trophic Diatom Index) showed the moderate water quality in the streams of the Valley. Like EU Water Framework Directive 2000/60/EC (WFD) India should also have the objective to ensure ecosystem integrity through bio-assessment and not just mere pollution control.
\end{abstract}

Keywords: Alkaliphilous, Degradation, Anthropogenic eutrophication, Indices, Saprobity

\section{INTRODUCTION}

After becoming the interim capital of the 27th state of India, Uttarakhand (formerly Uttaranchal), the face of Dehradun changed for ever, attributed primarily to population increase. The growth rate of population in Dehradun doubled in one decade from 447,808 in 2001 to 714,223 in 2011(Census of India, 2011). GIS studies show that the Dehradun urban area has almost doubled in one decade (1998 to 2008) i.e. from 746 ha area to 1463 ha area (Gupta 2013). In this duration max deviation in land-use occurred in the agricultural land (860.35) of which 740.50 was towards residential category (JNNURM, 2007). Most remarkable change has taken place in built up area resulting in $112.4 \%$ growth in less than a decade. The forest area has decreased by $3.75 \%$. (Tiwari and Khanduri, 2011). Out of the total 62.6 MLD sewage generated by 580,000 population only 32.1 MLD is collected. Rest 30.6 MLD is treated by individual septic tank and soak pit systems. Present gap in treatment capacity is 32 MLD (JNNURM, 2007). Sewage is discharged directly to Rispana or Bindal Rivers. In other streams such as the Guc- chupani, Sahastradhara and Lacchiwala area, streams and springs are used for water sport and tourist activity. Many streams cater to religious have been diverted for canal irrigation. Hardly any stream is free from direct interference. This in turn led to stress on water resources that are generally seen either as surface and groundwater resources.

The surface waters however, are actually ecosystems, the importance of which is being gradually realised as 'ecosystem services' the benefits provided by ecosystems to mankind; Millennium Ecosystem Assessment, 2005). The Doon valley has numerous streams that harbour a variety of biota; diatoms among producer community (Achnanthidium pyrenaicum (Hust.) H. Kobayasi, Cymbella excisa Krammer, may-flies and caddis-flies among invertebrate and fish like Golden mahseer -Tor putitora among vertebrate consumer community (Nautiyal et al., 2013, Nautiyal, 2014). Since the rivers and streams provide services to mankind, they must be viewed as ecosystem and not just surface water resource. Therefore, there is a need to assess the ecological state of the streams periodically. Diatoms were used to make this assessment, because 
they account for enormous share of the benthic (bottom dwelling) producer community in mountain streams. Diatoms are stationary and cannot escape any event. Hence, their exposure to pollutants or changes in landscape in the basin is continuous, thus reflecting the present and past history of the water quality in the river, allowing detection of disturbances that might otherwise be missed (Eekhout et al., 1996). They have all ingredients of an indicator organism (Dixit et al., 1992), most important among which is to have a wide range of distribution at any time (Acs et al., 2004).

The unicellular diatoms are quite sensitive to major changes in environment of water bodies and frequently used as biological indicators of water quality. Using diatom as a tool for the purpose of assessment of ecological conditions in river and stream have a long history as autecological indices of diatom were developed to infer ecological status of water bodies based on the diatom species composition and the ecological preference and tolerance of taxa (Lowe, 1974, LangeBertalot, 1979, Van Dam et al., 1994, Prygiel et al., 1999). The diatom indices have been widely used in various region of the world for monitoring water quality; Watanabe et al. (1986) in Japan, Lobo et al. (1995, 2004) in Brazil, Solak and Acs (2011) in Turkey. In India studies on the use of diatoms for monitoring are scarce; rivers and lakes of south India (Venkatachalapathy and Karthikeyan 2012, Venkatachalapathy et al. 2014, Murulidhar and Murthy 2014, Mahadev et al. 2016), Central India (Srivastava et al. 2017) mountain streams and rivers in lesser Himalaya (Nautiyal et al. 2007, 2015, Nautiyal and Mishra 2013).

\section{MATERIALS AND METHODS}

Study area: Doon Valley is a unique small longitudinal, intermontane, synclinally depressed geographical entity in the midst of long Himalaya. It is bound by the high rising lesser Himalaya and low hills of the Siwalik, while the eastern and western limits were formed by the Ganga and Yamuna rivers, respectively. The Song and its tributaries flow down eastward from the slopes of Mussorie region and join the Ganga midway Rishikesh-Haridwar while the Asan and its tributaries flow down westward and join the Yamuna near Rampur (midway Herbertpur and Paonta Sahib along NH 72). A ridge passing through the Dehradun city along Rajpur road forms the water divide. Thus the valley is divisible into eastern and western Doon. Since the purpose of the study was to capture the ecological state of streams passing differentially populated parts of the valley and not the stream 'per se', the valley from Rishikesh-Haridwar boundary to Lacchiwala (outskirts of Doiwala) was labelled as Eastern Doon, MaldevtaPremnagar- Jhajra to Clement town-Mothrowala (encompassing the main city) as Central Doon and the rest as Western Doon. In eastern Doon (ED) Song River was sampled at Nepali Farm (S1), Bangala Rao at Shyampur (S2), Teen Pani at Chidderwala (S3) and diverted channel of Song at Lachhiwala (S4), . In central Doon (CD) Suswa river was sampled at Mothronwala (S5), Stream at Mothronwala (S6), Maldi river at Maldevata (S7), and Baldi river at Sahastradhara (S8). In the western Doon Tons Nadi was sampled at Guchhupani (S9) and Tapkeshwar (S10), Asan nadi at Buddhi (S11) and Amlawa stream at Kalsi (S12, Fig 1, and Table 1). The ambient temperatures and rainfall are uniform across the valley, except in the proximity of Mussorie.

Methodology: Benthic diatom samples were collected at regular monthly intervals from March 2014 to February 2015. Sample were obtained by scraping the boulders and pebbles with brush and preserved in $4 \%$ formaldehyde solution. The sample was cleaned and processed according to Brun's method (Sarode and Kamat 1984). Permanent mounts were prepared in Naphrax and subjected to identification with oil immersion lens (x1500). Total 350-400 valves of diatom species were enumerated using standard literature used in the previous studies (Nautiyal 2014). The counts data in excel sheets were imported into the software OMNIDIA (Lecointe et al 1993) in desired format to determine the ecologic values of Van Dam, Hofmann, Lange-Bertalot and indices of Leclercq (which show degradation, organic pollution, anthropogenic eutrophication) IBD, IPS and TDI that indicate water quality. These indices are computed after the software launches analysis after importing the data.

All these indices are meant to assess the level of pollution but the Van Dam categories $\mathrm{pH}$, salinity, oxygenation, $\mathrm{N}_{2}$ uptake, saprobic, trophic and moisture conditions on the scale of 1-7 (8-9 for Hofman trophic and saprobic conditions). Except for $\mathrm{pH}$, category 1 represents the best and 7 worse condition. Each Class/ Category is expressed by a term or phrase which is either self-explanatory or explained in terms of water chemistry (Appendix I). The ecologic value analysis in the software displays the share of diatom species in each category, but majority of species belong to one category "dominant" and the numeral representing the "dominant" category is displayed in the last column of the output, implying what kind of water chemistry prevails in the stream with respect to concerned characteristic (Table 2).

\section{RESULTS AND DISCUSSION}

The ecological state of streams located in the valley were characterised by the ecologic values of Van Dam 1994, Lange-Bertalot 1979, Hofmann 1994 and other diatom indices.

pH: In respect of $\mathrm{pH}$, Van Dam values reveal alkaliphilous condition ( $4=$ mainly occurring at $\mathrm{pH}>7)$ in most of the streams except S8, S9 (located in CD) 


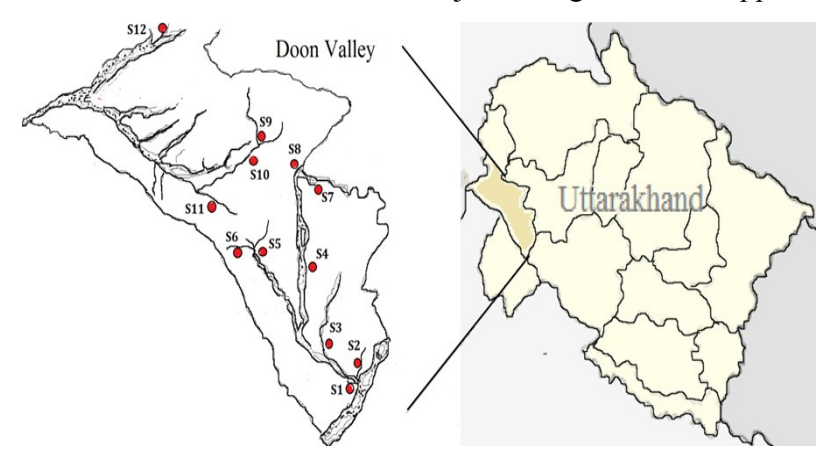

Fig 1. Location of streams sampled in the Doon Valley.

characterised by circumneutral condition ( $3=$ mainly occurring at $\mathrm{pH}$ values about 7). The Van Dam $\mathrm{pH}$ was supported by Hakansson $\mathrm{pH},(7=$ alkaliphilous $)$ for most of the streams except $\mathrm{S} 8$ and $\mathrm{S} 9$ where $\mathrm{pH}$ was circumneutral (3).

Salinity: All streams exhibit fresh-brackish $\left(2=\mathrm{Cl}^{-}\right.$ $<500 \mathrm{mgl}^{-1}$ and salinity $<0.9 \%$ ) water.

$\mathbf{N}_{2}$ uptake: The best condition is indicated by category $1\left(\mathrm{~N}_{2}\right.$ autotrophic taxa tolerating very small concentration of organically bound nitrogen) which was observed only at S8 and S9. In all streams category $2\left(\mathrm{~N}_{2}\right.$ autotrophic taxa tolerating elevated concentration of organically bound nitrogen) prevailed in all the streams of ED and most of the streams of CD and WD. Oxygenation: The best condition i.e. continuously high denoted by category 1 (100\% saturation) was observed in some streams S4, S7, S8, S9, S10 and S12. Decline in the oxygenation indicated by category 2 (Fairly high $75 \%$ saturation) was observed (at S1, S2, S3 and S5 in while moderate $(3=50 \%$ saturation) and low $(4=30 \%)$ oxygenation were recorded at S11 and S6, respectively (Table 2). Therefore the streams of the valley exhibited varied oxygenation conditions and hence comparable to the lower stretch of lesser Himalayan river Mandakini (Nautiyal et al. 2015).

Saprobity: The oligosaprobous condition denoted by category $1\left(=\mathrm{BOD}<2 \mathrm{mgl}^{-1}\right)$ were observed at S8, S9 and $\mathrm{S} 10$, while category 2 ( $\beta$-mesosaprobous condition (=BOD 2-4 $\mathrm{mg} \mathrm{l}^{-1}$ ) for most of the streams. Hofmann saprobity also indicated $\beta$ - $\alpha$-mesosaprob $\left(5^{\text {th }}\right.$ category) at S1, S2, S3, S4, S5 and S12. Oligo- $\beta$ mesosaprob (2) at was recorded at $\mathrm{S} 8, \mathrm{~S} 9, \mathrm{~S} 10$ while $\beta$ -mesosaprob (3), $\alpha$-mesosaprob (7) and $\alpha$ mesopolysaprob (8) were recorded at S6, S7 and S11 respectively (Table 2). According to Lange-Bertalot value, in most of the streams more sensible $\left(5^{\text {th }}\right.$ category) taxa were recorded except for S5 and S11 in which most pollution tolerant (1) and $\alpha$-mesosaprobic taxa were found, respectively. As evident from the BOD levels for category, the saprobity levels are an indicator of the presence of organic wastes in the water. Both Van Dam and Hofmann values indicate similar levels of saprobic conditions. The Lange-Bertalot values use the category 'sensible' to indicate the presence of dia-

Table 1. Details of Sampling sites with map variables.

\begin{tabular}{|c|c|c|c|}
\hline $\begin{array}{l}\text { Name of stream / } \\
\text { Sampling station }\end{array}$ & Coordinates & Altitude (masl) & Land Use \\
\hline \multicolumn{4}{|l|}{ Eastern Doon (ED) } \\
\hline \multirow{3}{*}{ Song Nadi/ Nepali Farm (S1) } & $30.05511 \mathrm{~N}$ & & \multirow{5}{*}{$\begin{array}{l}\text { Semi-urban and forest } \\
\text { Agriculture and human settle- } \\
\text { ment }\end{array}$} \\
\hline & $78.21732 \mathrm{E}$ & 345 & \\
\hline & $30.06137 \mathrm{~N}$ & & \\
\hline \multirow[t]{2}{*}{ Bangala Rao/Shyampur (S2) } & $78.23130 \mathrm{E}$ & 343 & \\
\hline & $30.06868 \mathrm{~N}$ & & \\
\hline \multirow[t]{2}{*}{ Teen Pani/Chhiderwala } & $78.20699 \mathrm{E}$ & 360 & Agriculture and forest \\
\hline & $30.212594 \mathrm{E}$ & & \\
\hline Song Nadi/Lachhiwala & $78.135755 \mathrm{~N}$ & 526 & Forest and agriculture \\
\hline \multicolumn{4}{|l|}{ Central Doon (CD) } \\
\hline \multirow{3}{*}{ SuswaNadi/Mothrowala } & $30.23889 \mathrm{E}$ & & \\
\hline & $78.02489 \mathrm{~N}$ & 557 & Agriculture/forest and town \\
\hline & $30.24096 \mathrm{E}$ & & \\
\hline \multirow[t]{2}{*}{ Stream/Mothronwala } & $78.02139 \mathrm{~N}$ & 624 & Forest \\
\hline & $30.35568 \mathrm{E}$ & & \\
\hline \multirow[t]{2}{*}{ MaldiNadi/Maldevata } & $78.13980 \mathrm{~N}$ & 764 & Forest and Agriculture \\
\hline & $30.38834 \mathrm{E}$ & & \\
\hline BaldiNadi/Sahastradhara & $78.13136 \mathrm{~N}$ & 843 & Tourist place and Forest \\
\hline \multicolumn{4}{|l|}{ Western Doon (WD) } \\
\hline \multirow{3}{*}{ Tons River/Guchhupani } & $30.37514 \mathrm{E}$ & & \\
\hline & $78.05776 \mathrm{~N}$ & 754 & Tourist place and Forest \\
\hline & $30.35699 \mathrm{E}$ & & \\
\hline \multirow[t]{2}{*}{ Tons Nadi/Tapkeshwer } & $78.01818 \mathrm{~N}$ & 660 & Tourist place and Forest \\
\hline & $30.36659 \mathrm{E}$ & & \\
\hline \multirow{2}{*}{ AsanNadi/Budhi } & $78.041818 \mathrm{~N}$ & 630 & Town and agriculture \\
\hline & $30.52279 \mathrm{E}$ & & \\
\hline AmlawaNadi, Kalsi & 77.85289 & 547 & Agriculture and forest \\
\hline
\end{tabular}


Table 2. Ecological state of different streams in the Doon Valley: Dominant category (Interpretation of ecologic values are explained in the Appendix I and II.

\begin{tabular}{|c|c|c|c|c|c|c|c|c|c|c|c|c|}
\hline & \multicolumn{4}{|c|}{ ED } & \multicolumn{4}{|c|}{ CD } & \multicolumn{4}{|c|}{ WD } \\
\hline & S1 & S2 & S3 & S4 & S5 & S6 & S7 & S8 & S9 & S10 & S11 & S12 \\
\hline \multicolumn{13}{|l|}{ Van Dam 1994} \\
\hline $\mathrm{pH}$ & 4 & 4 & 4 & 4 & 4 & 4 & 4 & 3 & 3 & 4 & 4 & 4 \\
\hline Saline & 2 & 3 & 2 & 2 & 2 & 2 & 2 & 2 & 2 & 2 & 2 & 2 \\
\hline N Heterotroph & 2 & 2 & 2 & 2 & 2 & 2 & 2 & 1 & 1 & 2 & 2 & 2 \\
\hline Oxygenation & 2 & 2 & 2 & 1 & 2 & 4 & 1 & 1 & 1 & 1 & 3 & 1 \\
\hline Saprobies & 2 & 2 & 2 & 2 & 2 & 2 & 2 & 1 & 1 & 1 & 2 & 2 \\
\hline Statuttrophique & 5 & 5 & 5 & 5 & 5 & 5 & 5 & 4 & 4 & 5 & 5 & 5 \\
\hline Aerophilie & 1 & 1 & 1 & 2 & 1 & 2 & 2 & 2 & 2 & 2 & 1 & 2 \\
\hline \multicolumn{13}{|l|}{ Lange-Brtalot 1979} \\
\hline Differential Species & 5 & 5 & 5 & 5 & 1 & 5 & 5 & 5 & 5 & 5 & 2 & 5 \\
\hline \multicolumn{13}{|l|}{ Hofmann 1994} \\
\hline Trophic & 5 & 5 & 5 & 4 & 4 & 6 & 5 & 6 & 5 & 4 & 5 & 5 \\
\hline Saprobie & 5 & 5 & 5 & 5 & 5 & 3 & 7 & 2 & 2 & 2 & 8 & 5 \\
\hline \multicolumn{13}{|l|}{ Hakansson 1993} \\
\hline $\mathrm{pH}$ & 7 & 7 & 7 & 7 & 7 & 7 & 7 & 5 & 5 & 7 & 7 & 7 \\
\hline \multicolumn{13}{|l|}{ Denys 1991} \\
\hline Habitat & 3 & 3 & 3 & 3 & 3 & 3 & 3 & 3 & 3 & 3 & 3 & 3 \\
\hline Courant & 4 & 4 & 4 & 4 & 4 & 4 & 4 & 4 & 4 & 4 & 4 & 4 \\
\hline
\end{tabular}

Table 3. Louis Leclercq index for Doon valley streams (Interpretation of ecologic values are explained in the Appendix III).

\begin{tabular}{lllllllllllll}
\hline & ED & \multicolumn{1}{c}{ CD } & \multicolumn{3}{c}{ WD } \\
\cline { 2 - 14 } & S1 & S2 & S3 & S4 & S5 & S6 & S7 & S8 & S9 & S10 & S11 & S12 \\
\hline Louis Leclercq IDSE & 3.4 & 3.3 & 3.5 & 3.5 & 3.0 & 3.4 & 3.3 & 3.8 & 4.4 & 3.0 & 3.3 & 3.4 \\
Indicators of OP in \% & 9.2 & 3.6 & 4.7 & 2.0 & 20.6 & 18.2 & 11.5 & 1.0 & 0.7 & 9.7 & 12.2 & 11.9 \\
Indicators of AE in \% & 31.5 & 37.2 & 25.3 & 24.8 & 29.1 & 16.5 & 13.2 & 15.5 & 5.6 & 10.5 & 28.9 & 17.3 \\
\hline
\end{tabular}

Table 4. Diatom indices for the streams of Doon valley. The interpretation of ecologic values are explained in the Appendix IV.

\begin{tabular}{|c|c|c|c|c|c|c|c|c|c|c|c|c|}
\hline & \multicolumn{4}{|l|}{ ED } & \multicolumn{4}{|l|}{ CD } & \multicolumn{4}{|l|}{ WD } \\
\hline & S1 & S2 & S3 & S4 & S5 & S6 & S7 & S8 & S9 & S10 & S11 & S12 \\
\hline IBD & 4.97 & 4.93 & 4.76 & 5.17 & 4.74 & 5.03 & 4.63 & 5.58 & 5.5 & 5.06 & 5 & 4.99 \\
\hline IPS & 3.73 & 2.68 & 3.72 & 3.98 & 2.9 & 3.71 & 3.15 & 4.17 & 4.24 & 3.67 & 3.41 & 3.54 \\
\hline TDI & 61.9 & 55.4 & 69.8 & 59.1 & 75.1 & 56.8 & 63.2 & 54.7 & 47.1 & 63.1 & 55.2 & 62.3 \\
\hline
\end{tabular}

toms that are sensitive to pollution synonymous with oligosaprobous condition of Van Dam.

Trophic state: The trophic status was observed to be eutraphentic ( $5^{\text {th }}$ category) for most of the streams except S8 and S9, where it was méso-eutraphentic $\left(4^{\text {th }}\right.$ category). Hofmann Trophic status was recorded to be eutraphentic (5) at S1,S2, S3,S7, S9, S11 and S12, while $\alpha$-meso-eutraphent ( $4^{\text {th }}$ category) was recorded at S4, S5, S10 and tolerant ( $6^{\text {th }}$ category) at S6 and S8 only. The moisture conditions indicated only the two types of diatom taxa in the community, never or very rarely occurring outside water bodies ( $1^{\text {st }}$ category) and mainly occurring in water bodies and sometimes on wet places were recorded in the streams of Valley ( $2^{\text {nd }}$ category).

Denys Life-form and courant represent the habitat as tychoplanktonic, epontic origin of taxa and indifferent current for all the streams of Doon Valley (Table 2).

Nautiyal and Mishra (2013) reported alkaliphilic, fresh -brackish, $\beta$-mesosaprobic (saprobity) and eutraphentic condition (trophic state) in the spring-fed Khanda Gad that is under anthropogenic influence. Nautiyal et al. (2007) observed similar ecological state in the snow- fed streams of Kakra sub-basin of the Mandakini basin.

The Louis Leclercq 2008 IDSE Degradation index indicated that the degradation of streams was largely moderate (3.5-3.0), except low (4.2-3.6) at S8 and R while non-existent (5.0-4.3) at S9 only. Organic Pollution (OP, in \%) was non-existent $(<10 \%)$ in some streams and low (10-20\%) in others. The Anthropogenic Eutrophication (AE, in \%) was low and moderate in most of the streams. It was non-existent at S9 only (Table 3). Therefore, the streams of the Doon Valley were moderately degraded and affected by the anthropogenic eutrophication.

Diatom indices, IBD varied from 4.63 at S7 to 5.58 at S8 and IPS from 2.68 at S2 to 4.24 at S9 indicating low to moderate water quality. Similarly, TDI which varied from 54.7 at S8 to 75.1 at S5 also indicated low to moderate water quality (Table 4). Similar indices have been used in various parts of the world, such as in tropical river from Taiwan (Wu and Kow 2002), in streams and spring from Brazil (Bere and Tundisi 2010), in rivers from Poland TDI and IPS showed the high and good ecological status in upper sections while the mid- 
Appendix I. Classification of Van Dam ecologic indicator values.

\begin{tabular}{|c|c|c|c|c|}
\hline $\mathrm{pH}$ & \multicolumn{2}{|c|}{$1 / 2 / 3 / 4 / 5 / 6$} & \multicolumn{2}{|c|}{$\begin{array}{l}\text { Acidobiontic (optimal occurrence at } \mathrm{pH}<5.5 \text { )/Acidophilous (mainly occurring at } \mathrm{pH}<7 \text { )/ } \\
\text { Circumneutral(mainly occurring at } \mathrm{pH} \text { values about } 7 \text { )/alkaliphilous (mainly occurring at } \mathrm{pH} \\
>7 \text { )/alkalibiontic (exclusively occurring at } \mathrm{pH}>7 \text { )/indifferent (no apparent optimum) }\end{array}$} \\
\hline Salinity & \multicolumn{2}{|c|}{$1 / 2 / 3 / 4$} & \multicolumn{2}{|c|}{$\begin{array}{l}\text { Fresh }(\mathrm{Cl}<100 \mathrm{mgl}-1 \text {; salinity }<0.2 \%) / \text { Fresh Brackish }(\mathrm{Cl}<500 \mathrm{mgl}-1 \text {; salinity }<0.9 \%) / \\
\text { Brackish fresh }(\mathrm{Cl} 500-1000 \text { mgl-1; salinity } 0.9-1.8 \%) / \text { Brackish }(\mathrm{Cl} 1000-5000 \text { mgl-1; salini- } \\
\text { ty } 1.8-9.0)\end{array}$} \\
\hline $\begin{array}{l}\text { Nitrogen Up- } \\
\text { take Metabo- } \\
\text { lism }\end{array}$ & \multicolumn{2}{|c|}{$1 / 2 / 3 / 4$} & \multicolumn{2}{|c|}{$\begin{array}{l}\text { Nitrogen autotrophic taxa, tolerating very small concentration of organically bound nitrogen/ } \\
\text { Nitrogen autotrophic taxa, tolerating elevated concentration of organically bound nitrogen/ } \\
\text { frequently nitrogen-heterotrophic taxa, needing periodically elevated concentrations of organ- } \\
\text { ically bound nitrogen/Obligately nitrogen-heterotrophic taxa, needing continuously elevated } \\
\text { concentration of organically bound nitrogen }\end{array}$} \\
\hline $\begin{array}{l}\text { Oxygen re- } \\
\text { quirements }\end{array}$ & \multicolumn{2}{|c|}{$1 / 2 / 3 / 4 / 5$} & \multicolumn{2}{|c|}{$\begin{array}{l}\mathrm{O}_{2} \text { continuously high }(100 \% \text { saturation }) / \text { fairly high }(75 \% \text { saturation }) / \text { moderate }(50 \% \text { satura- } \\
\text { tion }) / \text { low }(30 \% \text { sat. }) / \text { very low }(>10 \% \text { sat. })\end{array}$} \\
\hline Saprobity & \multicolumn{2}{|c|}{$1 / 2 / 3 / 4 / 5$} & \multicolumn{2}{|c|}{$\begin{array}{l}\text { Oligosaprobous }\left(\mathrm{BOD}<2 \mathrm{mg}^{-1}\right) / \beta \text {-mesosaprobous }\left(\mathrm{BOD} 2-4 \mathrm{mg}^{-1}\right) / \text { alpha-mesosaprobous } \\
(\text { BOD4-13)/alpha-mesopolysaprobous (BOD } 13-22) / \text { polysaprobous }(\mathrm{BOD}>22)\end{array}$} \\
\hline Trophic state & \multicolumn{2}{|c|}{$\begin{array}{l}1 / 2 / 3 / 4 / 5 / 6 / \\
7\end{array}$} & \multicolumn{2}{|c|}{$\begin{array}{l}\text { Oligotraphentic/oligo-meotraphentic/mesotraphentic/méso-eutraphentic/eutraphentic/ } \\
\text { hypereutraphentic/oligo to eutraphentic (hypereutraphentic) }\end{array}$} \\
\hline Moisture & \multicolumn{2}{|c|}{$1 / 2 / 3 / 4 / 5$} & \multicolumn{2}{|c|}{$\begin{array}{l}\text { Never or very rarely occurring outside water bodies/mainly occurring in water bodies, some- } \\
\text { times on wet places/mainly water bodies some time moist places/mainly occurring on wet and } \\
\text { moist or temporarily dry places/nearly exclusively occurring outside water bodies }\end{array}$} \\
\hline \\
\hline \multirow{2}{*}{\multicolumn{3}{|c|}{ Lange-Bertalot, $1979 \quad 1 / 2 \mathrm{a} /$}} & $\mathrm{b} / 2 \mathrm{c} / 3 \mathrm{a} / 3 \mathrm{~b}$ & 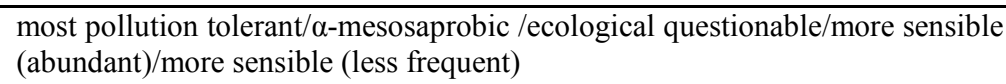 \\
\hline & & \\
\hline \multicolumn{2}{|l|}{ Trophic state } & \multicolumn{2}{|c|}{$0 / 1 / 2 / 3 / 4 / 5 / 6 / 7 / 8 /$} & $\begin{array}{l}\text { Unknown/oligotraphent/oligo } \beta \quad \text {-mesotraphent/- } \alpha \text {-meso-eutraphent/ } \\
\text { eutraphent/ tolerant/indifferent/saprotroph }\end{array}$ \\
\hline \multicolumn{2}{|l|}{ Saprobity } & \multicolumn{2}{|c|}{$0 / 1 / 2 / 3 / 4 / 5 / 6 / 7 / 8 / 9$} & $\begin{array}{l}\text { Unknown/oligosaprob/oligo- } \beta \text {-mesosaprob } / \beta \text {-mesosaprob/ } \beta \text {-meso- } \beta \text { - } \alpha \\
\text { meso/ } \beta \text { - } \alpha \text {-mesosaprob/ } \beta \text { - } \alpha \text {-meso- } \alpha \text { meso/ } \alpha \text {-mesosaprob/ } \alpha- \\
\text { mesopolysaprob/polysaprob }\end{array}$ \\
\hline \multicolumn{2}{|c|}{ Hakansson $\mathrm{pH}$ classes } & \multicolumn{2}{|c|}{$1 / 2 / 3 / 4 / 5 / 6 / 7 / 8 / 9$} & $\begin{array}{l}\text { Acidobiontic/acidobiontic to acidophilous/acidophilous/indifferent to acidoph- } \\
\text { ious/Indifferent (neutral circumstance)/alcaliphilous to indiffer- } \\
\text { alcaliphilious/alcaliphilous to alcalibiontic/alcalibiontic }\end{array}$ \\
\hline \multicolumn{2}{|c|}{$\begin{array}{l}\text { Habitat (Lifeform) } \\
\text { (Denys, 1991) }\end{array}$} & \multicolumn{2}{|c|}{$0 / 2 / 3 / 4 / 5 / 6 / 7 / 8$} & $\begin{array}{l}\text { Unknown/euplanktonic/Tychoplanktonic, epontic origin/ Tychoplanktonic, } \\
\text { benthic origin/ Tychoplanktonic, both epontic and benthic origin/epontic/ } \\
\text { epontic and benthic/benthic }\end{array}$ \\
\hline \multicolumn{2}{|l|}{ Current } & \multicolumn{2}{|c|}{$0 / 1 / 2 / 3 / 4 / 5$} & Unknown/not relevant/rheobiontic/rheophilous/indifferent/limniophilous \\
\hline
\end{tabular}

Appendix III. Levels of IDSE degradation, anthropogenic eutrophication (AE), organic pollution (OP).

\begin{tabular}{llll}
\hline State & Degradation & AE/OP & Colour \\
\hline Non-existence & $5.0-4.3$ & $<10 \%$ & \\
Low & $4.2-3.6$ & $10-20 \%$ & \\
Moderate & $3.5-3.0$ & $20.1-45 \%$ & \\
High & $2.9-2.3$ & $45.1-70 \%$ & \\
Very high & $2.2-1.0$ & $>70 \%$ & \\
\hline
\end{tabular}

dle and lower section were reported with moderate and poor ecological status (Nogal et al., 2013), in lakes from Spian moderate to good IBD has been reported (Antón -Garrido et al., 2013). In Europe, The Water Framework Directive (Directive 2000/60/EC of the European Parliament and of the Council of 23 October
2000 establishing a framework for Community action in the field of water policy) is a European Union directive which commits European Union member states to achieve good qualitative and quantitative status of all water bodies (including marine waters up to one nautical mile from shore) by 2015 (Winston et al., 2015).

\section{Conclusion}

Doon valley has plenty in water resources. $\beta$ mesosaprobic and eutraphentic state was observed in most streams of the Doon valley, especially Central Doon. Based on diatom indices also, the water quality was found to be quite average in the streams of the

Appendix IV. Diatom indices based inferences.

\begin{tabular}{lllll}
\hline Indices & Abbr & Quality Range & \\
\hline Indice biologique diatomèes (Lenoir and Coste 1995) & IBD & 1 (worse) & to 7 (best) \\
Indice de polluo-sensibilite (Cemagref, 1982) & IPS & 1 (worse) to 5 (best) \\
Trophic Diatom Index (Kelly and Whitton 1995) & TDI/100 & 0 (clean) & to & 100 (most polluted) \\
\hline
\end{tabular}


valley. The streams were moderately degraded and impacted by anthropogenic eutrophication (synonymous to eutrophication which refers to level of nutrients coming from human source) also. Localities in the in ED were comparatively more affected by degradation and anthropogenic activities, owing to dense habitation and run-offs from agriculture compared to religious and tourist, water-sport related activities in CD and to a certain extent along with agriculture-habitation in WD. The precious resource can be restored if littering or influx of wastes into streams can be prevented. Diatoms are useful tool for the bioassessment of the aquatic environments.

\section{ACKNOWLEDGEMENTS}

The authors (Rajbeer Singh, Prakash Nautiyal) acknowledge the academic support provided by H N B Garhwal University, Srinagar, Garhwal and RN thanks Department of Zoology, Government PG College Dakpathar, Vikasnagar, Dehradun for providing the laboratory facilities.

\section{REFERENCES}

Acs, E., Szabo, K., Toth, B. and Kiss, K. T. (2004). Investigations of benthic algal community (with special attention to benthic diatoms) in concern with reference conditions in WED. Act Bot. Hung., 46: 255-278.

Antón-Garrido, B., Romo, S. and Villena, M. J. (2013). Diatom species composition and indices for determining the ecological status of coastal Mediterranean Spanish lakes. Anales del Jardin Botánico de Madrid, 70(2): 122-135.

Bere, T. and Tundisi, J.G. (2010).Biological monitoring of lotic ecosystems: the role of diatoms. Brazilian of Journal Biol., 70 (3): 493-502.

Cemagre, F. (1982). Etude des méthodes biologiques d'appréciation quantitative d e la qualité des eaux. Rapport Q.E. Lyon - Agence de l'Eau Rhône-MéditerranéeCorse, $218 \mathrm{p}$.

Denys, L. (1991). A check-list of the diatoms in the Holocene deposits of the Western Belgian coastal plain with a survey of their apparent ecological requirements. I Introduction, ecological code and complète list. Professiona 1 paper. Ministèr edes Affaires Economiques, Service Géologique de Belgique, $41 \mathrm{p}$.

Dixit, S.S., P. Smol, J.C. Kingston and D.F.Charles (1992). Diatoms as powerful indicators of environmental change Env. Sc. kchnol, 26:23-33.

Eekhout, S., J.M. King and Wackernagel, A. (1997). Classification of South African rivers. Vol 1. Department of Environmental Affairs and Tourism, Pretoria.

Hakansson, S. (1993). Numerical methodsfor the inference of $\mathrm{pH}$ variations in mesotrophic and eutrophic lakes in Southern Sweden - A progress report. Diatom Res., 8: 349-370.

Hofmann, G. (1994). Aufwuchs-Diatomeen in Seen and ihre Eignung als Indikatoren der Trophie. Bibliotheca Diatomologica 30: 1-241.

JNNURM (2007). City development plan: Dehradun revised. Jawaharlal Nehru National Urban Renewal Mission GHK International, UK. pp. 1-211.
Kelly, M.G., Penny, C.J., Whitton, B.A. (1995). Comparative performance of benthic diatom indices used to assess river quality. Hydrobiologia, 302, 179-188.

Lange-Bertalot, H. (1979). Pollution tolerance of diatoms as a criterion for water quality estimation. Nova Hedwigia., 64: 285-303.

Lecointe, C., M. Coste and J. Prygiel 1993. "Omnidia": software for taxonomy, calculation of diatom indices and inventories management. In (ed.), H. van Dam Twelfth International Diatom Symposium. Hydrobiologia 269/270: 509-513.

Lenoir, A., Coste, M. (1994). Estimation de la qualité des eaux du bassin Rhin-Meuse à l'aide des communautés de diatomées benthiques. Agence de l'Eau Rhin-Meuse/ Cemagref Bordeaux, $169 \mathrm{p}$.

Lobo, E., A., Bes, D., Tudesque, L. and Ector L. (2004). Water quality assessment of the Pardinhoriver, RS, Brazil, using epilithic diatom assemblages and faecal coliforms as biological indicators. Vie Milieu. 54 (2-3): 115125.

Lobo, E., A., Katoh, K. and Aruga, Y. (1995).Response of epilithic diatom assemblages to water pollution in rivers in the Tokyo Metropolitan area, Japan,Freshwater water Biol. 34: 191-204.

Lowe, R. L. (1974). Environmental requirements and pollution tolerance of freshwater diatoms.US Environmental Protection Agency, EPA-670/4-74-007, 340.

Mahadev, J.,Shivakumar, K. V., Nagarathana, M., Ranganatha, A. D.(2016). Diatoms in detection of organic pollution and anthropogenic eutrophication in a polluted lake of Mysore, International J. of Science Technology \& Engineering, 2 (9): 366-368.

Millennium Ecosystem Assessment (2005). Ecosystems and human well-being: synthesis. Washington, DC: Island Press. ISBN 1-59726-040-1

Murulidhar, V.N. and Murthy Y. V.N. (2014). Distribution and ecology of diatom communities in four lakes using Lange-Bertalot method, International J. Curr. Microbiol. App. Sci. 3(4): 539-548.

Nautiyal, P. and Mishra, A. S. (2013).Epilithic diatom assemblages in a mountain stream of the lesser Himalaya (India): Longitudinal patterns. Int. J. Ecology Environmental Science,39(3): 171-185.

Nautiyal, P., Mishra, A. S. and Verma, J. (2015).The health of benthic diatom assemblages in lower stretch of a lesser Himalayan glacier-fed river, Mandakini, J. Earth Syst. Science, 124: 383-394.

Nautiyal, P., Nautiyal, R. and Verma, J. (2007). Ecological state of the diatom assemblages as indicators and water quality of Mandakini basin, Garhwal region (Lesser Himalayanstreams); In: Proceedings National Symposium on Limnology (eds) Venkatramani B, Puranik V D, Apte S K, Gour H N, Sharma S K, Sharma L L, Durve Y S, Gupta H C L, Verma P C and Sharma B K, February 19-21 200: Board of Research in Nuclear Sciences, Department of Atomic Energy, Mumbai, pp 284-287.

Nautiyal, R. (2014). Diatom communities in freshwater ecosystem of the Doon valley. Proceeding of the international Symposium on river biodiversity: GangaBrahmaputra-Meghna river system. pp. 293-335.

Nogal, T., Stanek-Tarkowska, J., Pajączek, A., Peszek, L. and Kochman, N. (2013).Ecological characterization of diatom communities in the Wisłokriver with application 
of their indicatory role to the evaluation of water quality,J. of Ecological Eng. 14 (4): 18-27.

Prygiel, J., Whitton, B. A. and Bukowska, J. (eds) (1999). Use of algae for monitoring rivers; III Agence de Leau, Artois.

Sarode, P.T. and Kamat, N.D. (1984).Fresh Water Diatoms of Maharashtra.338 pp. SaikripaPrakashan, Aurangabad, India.

Solak, C, N. and Acs, E. (2011). Water quality monitoring in European and Turkish rivers using diatoms, Turkish J. of Fishery and Aq. Science, 11: 329-337.

Srivastava, P., Grover, S., Verma, J. and Khan, A.S. (2017). Applicability and efficacy of diatom indices in water quality evaluation of the Chambal River in Central India. Environmental Science and Pollution Research DOI 10.1007/s11356-017-0166-0.

Tiwari, K. and Khanduri, K. (2011). Land Use / Land cover change detection in Doon valley (Dehradun Tehsil), Uttarakhand: using GIS \& Remote Sensing Technique. Int. J. of Geomatics and Geosc., 2(1): 34-41.

Van Dam, H., Martens, A. and Sinkeldam, J. (1994). A coded checklist and ecological indicator Values of freshwater diatoms from the Netherlands. Nether-lands $J$. Aquatic Ecol., 28: 117-133.
Venkatachalapathy, R. and Karthikeyan P. (2012). Environmental impact assessment of Cauvery river with diatoms at Bhavani Tamil Nadu India, Int. J. of Geology, Earth and Env.Science, 2(3): 36-42.

Venkatachalapathy, R. Nanthakumar, G. and Karthikeyan, P. (2014). Study of Diatoms and assessment of water quality in Yercaud Lake, Salem District, Tamil Nadu, South India, Gondwana Geological Magazine.Spl.,15: 13-16.

Watanabe, T., Asai, K., Houki, A., Tanaka, S. and Hizuka, T. (1986). Saprophilous and eurysaprobic diatom taxa to organic water pollution and diatom assemblage index (DAIPO), Diatom, 2: 23-73.

Winston, Y., Rita, E., Cestti, J. and Young, L. (2015). Toward Integrated Water Resources Management in Armenia. Inernational bank for Reconstruction and Development/The World Bank, $1818 \mathrm{H}$ streat NW, Washington, DC 20433.

Wu, J.T. and Kow, L.T. (2002). Applicability of a generic index for diatom assemblages to monitor pollution in the tropical river Tsanwun, Taiwan. $J$ of Applied Phyco., 14: 63-69.

Census of India (2011). www.census 2011 co.in Assessed on 12 October 2016 